\title{
Different methods to assess yield temporal stability in rubber
}

\author{
Lígia Regina Lima Gouvêa(1), Guilherme Augusto Peres Silva(1), Erivaldo José Scaloppi Junior(2) \\ and Paulo de Souza Gonçalves ${ }^{(1)}$
}

\begin{abstract}
(1)Instituto Agronômico de Campinas, Programa Seringueira, Caixa Postal 28, CEP 13001-970 Campinas, SP, Brazil. E-mail: lgouvea@iac.sp.gov.br, guilhermegoiania@gmail.com,paulog@iac.sp.gov.br (2)Agência Paulista de Tecnologia dos Agronegócios, Pólo Regional Noroeste Paulista, Caixa Postal 61, CEP 15500-970 Votuporanga, SP, Brazil. E-mail: scaloppi@apta.sp.gov.br
\end{abstract}

\begin{abstract}
The objective of this work was to assess, during six years, the temporal stability of natural rubber yield of 25 superior Hevea brasiliensis genotypes, using the Wricke, Eberhart \& Russell, Lin \& Binns, additive main effect and multiplicative interaction (AMMI) analysis, and harmonic mean of the relative performance of the genetic values (HMRPGV) methods. The IAC 40 and IAC 300 genotypes were identified as stable and high yielding by the Eberhart \& Russell, Lin \& Binns, HMRPGV, and AMMI Biplot methods. The ranking of the other more stable genotypes identified by these analyses was altered. The observed results in the AMMI Biplot agreed with those observed in the Wricke method for identifying stable, but lower yielding genotypes. The simultaneous use of different methods allows a more accurate indication of stable genotypes. Stability analyses based on different principles show agreement in indicating stable genotypes.
\end{abstract}

Index terms: Hevea brasiliensis, genotype selection, genotype x year interaction.

\section{Diferentes métodos para avaliar a estabilidade temporal do rendimento em seringueira}

\begin{abstract}
Resumo - O objetivo deste trabalho foi avaliar, durante seis anos, a estabilidade temporal da produção de borracha natural de 25 genótipos superiores de Hevea brasiliensis, utilizando os métodos de Wricke, Eberhart \& Russell, Lin \& Binns, análise dos efeitos aditivos principais e interação multiplicativa (AMMI) e média harmônica da performance relativa dos valores genéticos (MHPRV). Os genótipos IAC 40 e IAC 300 foram identificados como estáveis e produtivos, pelos métodos de Eberhart \& Russell, Lin \& Binns, MHPRV e Biplot AMMI. Houve alteração no ordenamento dos demais genótipos mais estáveis identificados a partir dessas análises. Os resultados observados no Biplot AMMI mostraram concordância com os observados no método de Wricke para a identificação de genótipos estáveis, mas menos produtivos. A utilização simultânea de diferentes métodos permite a indicação mais precisa de genótipos estáveis. Análises de estabilidade baseadas em diferentes princípios mostram concordância na indicação de genótipos estáveis.
\end{abstract}

Termos para indexação: Hevea brasiliensis, seleção de genótipos, interação genótipo x ano.

\section{Introduction}

The main source of natural rubber, Hevea brasiliensis (Willd. ex A. Juss.) Muell. Arg., is an important commercial species, which has been the object of genetic breeding to increase latex yield. However, this is a slow and laborious process, due to the perennial nature of the crop and to the several selection and assessment stages of the breeding cycle (Chandrasekhar et al., 2007; Priyadarshan et al., 2009). In one of these stages, the selection process involves assessing the adaptability and stability of genotypes in different environments.

Plant breeders usually estimate adaptability and phenotype stability parameters to assess new genotypes before recommending them as cultivars (Silva \& Duarte,
2006). In the case of $H$. brasiliensis, the most desirable genotypes are those that show stability in vigor and high yield over the years and locations (Gonçalves et al., 2003). Genotype x year interaction in perennial crops represents the different responses of genotypes to changes in annual conditions. In genotype $\mathrm{x}$ year interaction, the relative performance of genotypes varies with the year (Gonçalves et al., 2005).

Several methods, involving different assessment parameters, biometric procedures, or information detailing of analyses, can be used to assess stability and adaptability (Cruz \& Carneiro, 2006). In the method proposed by Wricke (1965), based on analysis of variance, the sum of squares of the interaction is divided into parts attributed to each genotype, and the genotype with the lowest estimate for ecovalence $(\omega t)$ is considered 
stable (Cruz et al., 2004). The method proposed by Eberhart \& Russell (1966), based on linear regression, measures the response of each genotype to environmental variations. Regression coefficients of each genotype, regarding the environmental index of the deviations of this regression, represent the estimates of the adaptability and stability parameters (Cruz et al., 2004). In the nonparametric analysis by Lin \& Binns (1988), the measurement used to estimate the stability and adaptability of cultivars is the mean of the square of the distance between the cultivar and the mean maximum response obtained in the environment (Cruz \& Carneiro, 2006). The additive main effect and multiplicative interaction (AMMI) model combines a univariate method, i.e., analysis of variance for additive effects of genotype and environment, with a multivariate method, i.e., analysis of principal components for multiplicative effect of genotype $\mathrm{x}$ environment interaction (Gauch \& Zobel, 1988). This method enables a more precise estimate of genotypic responses and an easy graphic interpretation of statistical analysis results by plot procedure (Zobel et al., 1988). According to Resende (2004), in the context of mixed models, the harmonic mean of the relative performance of the genetic values (HMRPGV), predicted by Blup, is an option for simultaneous selection based on yield, stability, and adaptability.

Recently, several methods have been used simultaneously to assess stability and adaptability in various crops, such as guarana (Nascimento Filho et al., 2009), cotton (Silva Filho et al., 2008), beans (Melo et al., 2007; Pereira et al., 2009a, 2009b), corn (Cargnelluti Filho et al., 2007), soybean (Silva \& Duarte, 2006), sugarcane (Rosse et al., 2002), and eucalyptus (Resende et al., 2001). In some cases, these methods can be complementary, since the simultaneous use of different methods generates estimates with different approaches (Pereira et al., 2009b).

The most recent studies on stability and adaptability regarding $H$. brasiliensis have been based on the Finlay \& Wilkinson (Gonçalves et al., 2009), Reml/Blup (Verardi et al., 2009), Eberhart \& Russell (Gonçalves et al., 2008), and GGE-Biplot (Priyadarshan et al., 2008) methods. However, there is no record of different methods being used simultaneously.

The objective of this work was to assess, during six years, the temporal stability of natural rubber yield of 25 superior $H$. brasiliensis genotypes, using the Wricke,
Eberhart \& Russell, Lin \& Binns, additive main effect and multiplicative interaction (AMMI) analysis, and harmonic mean of the relative performance of the genetic values (HMRPGV) methods.

\section{Materials and Methods}

A total of 25 genotypes were used in the experiment: one Malay clone (RRIM 600), eight Amazon clones (five IAN, two Fx, and one RO), and 16 local clones (IAC). The Amazon clones derived from crosses and selections made in Brazil by Ford and Instituto Agronômico do Norte (IAN); except RO 45, a primary clone, derived from unknown parents, from a collection in the state of Rondônia. The IAC clones are the result of crosses and selection by Instituto Agronômico de Campinas (IAC).

The experiment was set up in the experimental area of Pólo Regional Noroeste Paulista, at the Estação Experimental de Votuporanga, located in the northwestern region of São Paulo State, Brazil, at $20^{\circ} 25^{\prime} \mathrm{S}$ and $49^{\circ} 50^{\prime} \mathrm{W}$, at $450-\mathrm{m}$ altitude. The mean temperature during the growing season was $32^{\circ} \mathrm{C}$, and the mean annual rainfall was $1,480 \mathrm{~mm}$. The soil is classified as Paleudalf(Argissolo), with average nutrient status and poor physical structure. A randomized complete block design, with three replicates, was used. Each plot consisted of one row of six plants, with $7.0 \mathrm{~m}$ between rows and $3.0 \mathrm{~m}$ between plants. Rubber yield was assessed with half spiral tapping, at three-day intervals, five days a week, during eleven months of the year. Yield was measured by the amount of coagulated latex in the bowls, which were attached to each tapped tree and collected randomly twice a month; the latex was dried under normal shade and ventilation conditions during the assessment period. The total annual rubber yield per tree was divided by the number of coagulates, and the results were expressed in grams per tree per tapping.

Data were subjected to individual and joint analyses of variance. After verifying significant genotype $\mathrm{x}$ year interaction, analyses of genotype adaptability and phenotype stability were carried out using the Wricke (1965), Eberhart \& Russell (1966), Lin \& Binns (1988), AMMI (Zobel et al., 1988), and Blup prediction (HMRPGV) methods, described by Resende (2004). The analyses of the first three methods were carried out using the Genes program (Cruz, 2006), while the analyses of the fourth and fifth methods were done with 
the SAS (SAS Institute, 2002) and the Selegen Reml/ Blup (Resende, 2007) programs, respectively. The statistical models used in these analyses are described below.

The stability of the genotypes by the Wricke method was estimated by:

$$
\omega_{\mathrm{i}}=\sum_{\mathrm{i}} \sum_{\mathrm{j}}\left[\mathrm{Y}_{\mathrm{ij}}-\left(\mathrm{Y}_{\mathrm{i} .} / \mathrm{L}\right)-\left(\mathrm{Y}_{\mathrm{j} j} / \mathrm{G}\right)+(\mathrm{Y} . . / \mathrm{GL})\right]^{2},
$$

in which: $\omega t$ is the contribution of the ith genotype in the total of the interaction; $Y_{i j}$ is the mean of the ith genotype in environment $j ; Y_{i}$ is the total of the ith genotype in all locations; $Y_{j}$ is the total of environment $\mathrm{j}$ considering all genotypes;

$$
\mathrm{Y}_{. .}=\sum_{\mathrm{i}} \sum_{\mathrm{j}} \mathrm{Y}_{\mathrm{ij}},
$$

in which: $\mathrm{G}$ is the number of genotypes assessed; and $\mathrm{L}$ is the number of experimental locations.

In the analysis by Eberhart \& Russell (1966), the linear regression model was represented by:

$$
\mathrm{Y}_{\mathrm{ij}}=\mathrm{m}_{\mathrm{i}}+\mathrm{b}_{\mathrm{i}} \mathrm{I}_{\mathrm{j}}+\mathrm{d}_{\mathrm{ij}}+\overline{\mathrm{e}}_{\mathrm{ij}} \text {, }
$$

in which: $Y_{i j}$ is the observed mean of the ith genotype in environment $\mathrm{j} ; \mathrm{m}_{\mathrm{i}}$ is the general mean of the ith genotype; $b_{i}$ is the regression coefficient of the ith genotype; $I_{j}$ is the jth environmental index; $d_{i j}$ is the deviation of the regression of the ith genotype in the jth environment; and $\overline{\mathrm{e}}_{\mathrm{ij}}$ is the mean error associated to the mean. With this methodology, two stability parameters were estimated: regression coefficient $\left(\beta_{\mathrm{i}}\right)$, i.e., the regression of the performance of each genotype in different years on the annual mean over all genotypes, and variance of the deviation $\left(\hat{\mathrm{S}}_{\mathrm{d}}^{2}\right)$ from the regression line. The coefficient of determination $\left(\mathrm{R}^{2}\right)$ for regression was used to determine how well the linear model fit the data. The environmental index was calculated by:

$$
I_{j}=\bar{Y}_{j}-\bar{Y}_{. .} \text {, with } \sum_{j=1}^{n} I_{j}=0,
$$

in which $\mathrm{n}$ is the number of environments.

In the method by Lin \& Binns, Pi is the mean quadratic distance between genotype $i$ and the genotype with maximum response in environment $j$, as follows:

$$
P i=\sum_{j=1}^{n}\left(Y_{i j}-M_{j}\right)^{2} / 2 n,
$$

in which: Pi is the superiority index of the ith genotype; $\mathrm{Y}_{\mathrm{ij}}$ is the yield of the ith genotype in the jth environment; $\mathrm{M}_{\mathrm{j}}$ is the yield of the genotype with maximum response among all genotypes in the jth environment; and $\mathrm{n}$ is the number of environments. Modifications were used to discriminate Pi values for favorable and unfavorable environments, as reported in Cruz \& Carneiro (2006).

The model below was used in AMMI analysis, which involves additive components to study principal effects, and multiplicative components to study interaction:

$$
\mathrm{Y}_{\mathrm{ij}}=\mu+\mathrm{g}_{\mathrm{i}}+\mathrm{e}_{\mathrm{j}}+\sum_{\mathrm{k}=1}^{\mathrm{n}} \lambda_{\mathrm{k}} \gamma_{\mathrm{ik}} \alpha_{\mathrm{jk}}+\rho_{\mathrm{ij}}+\varepsilon_{\mathrm{ij}}
$$

in which: $Y_{\mathrm{ij}}$ is the mean response of the ith genotype $(i=1,2, \ldots, G$ genotypes) in the $j$ th environment $(j=1,2, \ldots$, A environments); $\mu$ is the general mean of the experiments; $g_{i}$ is the fixed effect of the ith genotype; $e_{j}$ is the fixed effect of the jth environment; $\lambda_{\mathrm{k}}$ is the kth singular value (scale) of the original interaction matrix (shown by GA); $\gamma_{\mathrm{ik}}$ is the element corresponding to the ith singular vector column of the GA matrix; $\alpha_{\mathrm{jk}}$ is the element corresponding to the $\mathrm{jth}$ environment in the kth singular vector line of the GA matrix; $\rho_{\mathrm{ij}}$ is the noise associated to the $(\mathrm{ga})_{\mathrm{ij}}$ term of the classic interaction of the ith genotype with the jth environment $\mathrm{j}$; and $\varepsilon$ is the mean experimental error.

The HMRPGV from the program Selegen-Reml/ Blup, which is used for complete block designs with temporal stability and adaptability, according to the statistical model number 79, was used in the joint selection for yield, stability, and adaptability of genetic materials:

$$
\mathrm{y}=\mathrm{Xm}+\mathrm{Zg}+\mathrm{Wp}+\mathrm{Ti}+\mathrm{Qs}+\varepsilon,
$$

in which: $y$ is the data vector; $m$ is the vector of the effects of evaluation-replicate combinations (assumed as fixed) added to the general mean; $g$ is the vector of the genotypic effects (assumed to be random); $p$ is the vector of the plot effects (random); $i$ is the vector of the effects of genotype $x$ evaluation interaction; $s$ is the vector of the permanent environment effects (random); and $\varepsilon$ is the error or residue vector (random). The uppercase letters represent the incident matrices for the referred effects. Genotypic effects were considered to be random due to the number of genotypes assessed, i.e., a total of 25 . Resende \& Duarte (2007) recommend treating genotypic effects as random when the number of treatments is equal to or greater than ten. 


\section{Results and Discussion}

Highly significant $(\mathrm{p}<0.01)$ effects were observed in the individual variance analyses of the genotypes for rubber yield each year, suggesting that the differences among the genotypes within each year were attributable to genetic causes. The joint analysis of variance showed highly significant effects $(\mathrm{p}<0.01)$ for genotypes, years, and genotype $\mathrm{x}$ year interaction, which indicates, respectively, presence of variability among genotypes, differences between years, and differences in the relative performance of genotypes in the years assessed.

Since the focus of the present study was to select stable genotypes over time, comparisons between the different methods of stability assessment concentrated mainly on the genotype with the best performance for the parameters assessed.

Table 1. Estimates of phenotypic stability obtained by the Wricke method, and mean rubber yield (grams per tree per tapping) of 25 Hevea brasiliensis genotypes assessed, during six years.

\begin{tabular}{lccccc}
\hline Genotype & Rubber yield $^{(1)}$ & Rank & Ecovalence $(\omega \mathrm{c})^{(2)}$ & $(\%)$ & Rank \\
\hline IAN 4493 & 33.233 & 17 & 129.19 & 0.6077 & 1 \\
IAC 307 & 42.632 & 9 & 197.66 & 0.9298 & 2 \\
IAC 310 & 31.521 & 20 & 220.52 & 1.0373 & 3 \\
IAC 313 & 39.437 & 12 & 254.06 & 1.1986 & 4 \\
IAC 302 & 41.441 & 10 & 269.20 & 1.2663 & 5 \\
IAC 309 & 34.384 & 16 & 328.06 & 1.5431 & 6 \\
IAC 314 & 26.509 & 25 & 345.49 & 1.6252 & 7 \\
IAN 6721 & 31.951 & 18 & 380.67 & 1.7906 & 8 \\
IAC 308 & 39.768 & 11 & 381.93 & 1.7965 & 9 \\
IAC 311 & 31.703 & 19 & 420.34 & 1.9772 & 10 \\
IAN 6323 & 31.417 & 21 & 422.98 & 1.9897 & 11 \\
RRIM 600 & 50.068 & 7 & 477.67 & 2.2469 & 12 \\
IAC 316 & 30.92 & 22 & 560.19 & 2.6350 & 13 \\
IAC 300 & 52.722 & 4 & 620.61 & 2.9193 & 14 \\
IAC 312 & 29.003 & 23 & 678.07 & 3.1896 & 15 \\
Fx 985 & 36.386 & 15 & 788.58 & 3.7094 & 16 \\
IAN 3703 & 38.632 & 13 & 809.89 & 3.8096 & 17 \\
IAC 306 & 28.616 & 24 & 984.64 & 4.4905 & 18 \\
IAC 40 & 66.737 & 1 & 972.73 & 4.5756 & 19 \\
Fx 3899 & 38.316 & 14 & 1031.10 & 4.8501 & 20 \\
IAC 301 & 55.226 & 2 & 1497.40 & 7.0434 & 21 \\
RO 45 & 51.494 & 6 & 1545.5 & 7.2696 & 22 \\
IAC 56 & 54.398 & 3 & 1765.00 & 8.3025 & 23 \\
IAC 303 & 52.591 & 5 & 3082.50 & 14.5000 & 24 \\
IAN 3156 & 48.719 & 8 & 3124.40 & 14.697 & 25 \\
\hline
\end{tabular}

${ }^{(1)}$ Mean yield of six years. ${ }^{(2)} \omega \mathbf{1}$, stability parameter.
Table 1 shows the stability parameters $(\omega \imath)$ obtained with the Wricke method, based on analysis of variance, in which the lowest values indicate greater stability. The most stable genotypes (IAN 4493, IAC 307, IAC 310, IAC 313, and IAC 302) were not amongst the highest yielding; the genotypes identified as least stable (IAN 3156, IAC 303, IAC 56, RO 45, and IAC 301) had better yields. According to Cargnelutti Filho et al. (2007), the Wricke method does not depend on the mean yield or on the response to variations in environmental conditions (adaptability); thus, methods based on analysis of variance may not be very efficient. Nascimento Filho et al. (2009) reported similar results to those obtained in the present study, but for guarana [Paullinia cupana var. sorbilis (Mart.) Ducke], while using a method based on analysis of variance. The authors verified that the clones with minimum variance among the environments were generally lower yielding and highly stable, but not of interest for breeding to increase yield. In the case of the genotypes used in the present study, which had been previously assessed and selected, even those with lower yields have potential for use. The results found for the most stable genotype agreed with those found in AMMI analysis. Silva Filho et al. (2008) and Silva \& Duarte (2006) also observed agreement between the Wricke method and AMMI analysis in cotton and soybean, respectively.

The parameters obtained by the Eberhart \& Russell method are shown in Table 2. High values were observed for the determination coefficient $\left(\mathrm{R}^{2}\right)$, indicating that the genotypes fitted the stability model. Eighteen of the 25 genotypes assessed showed nonsignificant deviations from the regression $\left(\hat{\mathrm{S}}_{\mathrm{di}}^{2}=0\right)$, indicating stability. The Fx 3899, IAC 301, IAC 303, IAC 56, IAN 3156, IAN 3703 , and RO 45 genotypes did not show stability. Regarding adaptability, six genotypes (IAC 303, IAC 56, IAC 40, RO 45, IAC 301, and RRIM 600) showed specific adaptability in favorable environments $\left(\hat{\beta}_{\mathrm{i}}>1.0\right)$, while genotypes IAN 3156, IAC 306, Fx 985, and IAC 314 showed specific adaptability for unfavorable environments $\left(\hat{\beta}_{i}<1.0\right)$. The genotypes showed general adaptability $\left(\hat{\beta}_{\mathrm{i}}=1.0\right)$. According to Resende et al. (2001), genotypes with $\left(\hat{\beta}_{\mathrm{i}}=1.0\right)$ are only desirable if they have maximum yield. IAC 40, IAC 300, and the control RRIM 600 were among the highest yielding stable genotypes, and were considered stable by the Lin \& Binns, HMRPGV, and AMMI1 biplot analyses. There was agreement among the genotypes that showed 
specific adaptability in favorable environments by the Eberhart \& Russell method and by the Lin \& Binns method. Cargnelutti Filho et al. (2007), Silva Filho et al. (2008), and Nascimento Filho et al. (2009) found agreement between the Eberhart \& Russell and Lin \& Binns methods.

Table 3 shows the ranking of the genotypes according to the Lin \& Binns method for stability, adaptability, and yield, with the alteration proposed by Cruz \& Carneiro (2006), which separates clones with greater stability and phenotypic adaptability for favorable and unfavorable environments $(<\mathrm{Pi})$. IAC 40 was classified as the most stable and adapted genotype in favorable and unfavorable environments, whereas IAC 300 was among the most stable and adapted in

Table 2. Estimates of phenotypic stability and adaptability obtained by the Eberhart \& Russell method, and mean rubber yield (gram per tree per tapping) of 25 Hevea brasiliensis genotypes assessed, during six years.

\begin{tabular}{lccccc}
\hline Genotype & Rubber yield $^{(1)}$ & Rank & $\hat{\beta}_{\mathrm{i}}$ & $\hat{\mathrm{S}}_{\mathrm{di}}^{2}$ & $\hat{\mathrm{R}}_{\mathrm{i}}^{2}(\%)$ \\
\hline Fx 3899 & 38.3161 & 14 & 0.7265 & $48.6314 *$ & 61.3825 \\
Fx 985 & 36.3861 & 15 & $0.6478^{*}$ & 18.0133 & 69.1596 \\
IAC 300 & 52.7217 & 4 & 1.1437 & 25.8523 & 85.3667 \\
IAC 301 & 55.2256 & 2 & $1.3158^{*}$ & $82.2139 * *$ & 77.9023 \\
IAC 302 & 41.4411 & 10 & 0.8952 & -1.3866 & 89.3772 \\
IAC 303 & 52.5911 & 5 & $1.5952^{*} *$ & $160.5526 * *$ & 74.6954 \\
IAC 306 & 28.6161 & 24 & $0.4983 * *$ & 4.8952 & 66.5147 \\
IAC 307 & 42.6317 & 9 & 1.1681 & -10.9963 & 96.4821 \\
IAC 308 & 39.7683 & 11 & 1.1093 & 7.8044 & 89.8646 \\
IAC 309 & 34.3839 & 16 & 0.9109 & 4.1587 & 87.2256 \\
IAC 310 & 31.5206 & 20 & 0.7356 & -17.8916 & 96.9370 \\
IAC 311 & 31.7033 & 19 & 0.9378 & 12.7089 & 84.4452 \\
IAC 312 & 29.0028 & 23 & 0.7146 & 17.8020 & 73.2885 \\
IAC 313 & 39.4367 & 12 & 1.1420 & -4.5250 & 94.1934 \\
IAC 314 & 26.5094 & 25 & $0.6635^{*}$ & -16.6270 & 95.0171 \\
IAC 316 & 30.9200 & 22 & 0.7343 & 10.2692 & 78.1839 \\
IAC 40 & 66.7372 & 1 & $1.5485^{* *}$ & -3.9745 & 96.6544 \\
IAC 56 & 54.3983 & 3 & $1.5661 * *$ & $57.8997 * *$ & 86.7083 \\
IAN 3156 & 48.7189 & 8 & $0.3521 * *$ & $150.2240 * *$ & 13.2301 \\
IAN 4493 & 33.2333 & 17 & 0.8120 & -18.2022 & 97.6838 \\
IAN 3703 & 38.6322 & 13 & 1.1446 & $41.5731 * *$ & 81.4344 \\
IAN 6323 & 31.4172 & 21 & 0.9318 & 12.7632 & 84.2536 \\
IAN 6721 & 31.9506 & 18 & 1.0056 & 10.2136 & 87.0699 \\
RO 45 & 51.4944 & 6 & $1.3888^{*}$ & $75.3584 * *$ & 80.7889 \\
RRIM 600 & 50.0683 & 7 & $1.3119 *$ & -2.2406 & 94.9672 \\
\hline
\end{tabular}

${ }^{(1)}$ Mean yield of six years. $\hat{\beta}_{i}$, regression coefficient. $H_{0}, \hat{\beta}_{i}=1$ and $\mathrm{H}_{\mathrm{A}}, \hat{\beta}_{\mathrm{i}} \neq 1$. * and ${ }^{*}$ Significant by the t test at 5 and $1 \%$ probability, respectively. $\hat{\mathrm{S}}_{\mathrm{di}}^{2}$ : deviation of the regression coefficient. $\mathrm{H}_{0}, \hat{\mathrm{S}}_{\mathrm{di}}^{2}=0$ and $\mathrm{H}_{\mathrm{A}}, \hat{\mathrm{S}}_{\mathrm{di}}^{2} \neq 0$. * and **Significant by the f test, at 5 and $1 \%$ probability, respectively. $\hat{\mathrm{R}}_{\mathrm{i}}^{2}$, determination coefficient. general and unfavorable environments. Genotypes IAC 303, IAC 56, IAC 301, and RRIM 600 showed specific adaptability to favorable environments, while IAN 3156, IAC 300, IAC 301, and RO 45 had specific adaptability to unfavorable environments. Besides identifying the most stable and adaptive genotypes among the highest yielding, the Lin \& Binns method is easy to apply and interpret, and discriminates the best clones for performance in both favorable and unfavorable environments (Nascimento Filho et al., 2009; Pereira et al., 2009a).

In the analyses carried out by HMRPGV (Table 4), IAC 40 and IAC 300 were among the first genotypes for all the parameters assessed. The highest genetic values for stability were found for IAC 40, IAC 3156 , IAC 300, IAC 301, and IAC 303, and the greatest adaptability was found for IAC 40, IAC 300, IAC 3156, IAC 301, and IAC 56. The genotypes that showed highest stability and adaptability were IAC 40, IAC 300, IAC 301, IAC 3156, and IAC 56. As observed by Maia et al. (2009), there are similarities among the rankings of these materials by the different methods. According to the authors, this could be a result of the positive correlation and the mean magnitude involving genotypic performance in the environments.

Five components were obtained by AMMI analysis (IPCA). There was significance up to the AMMI2 model, which was the first to associate significance for axles (IPCA) with nonsignificance for residue (noise). According to Gauch (1988), the first AMMI axles capture a greater percentage of pattern. The subsequent increase in dimensions (axles) results in a decrease in the percentage of pattern and in an increase in noise. Therefore, in spite of selection on a single axle, which explains a small portion of the original sum of squares of the genotype $x$ environment interaction $\left(\mathrm{SS}_{\mathrm{GxE}}\right)$, the capture of a greater percentage of pattern was expected. In the present study, the first axle (IPCA 1) explained $51.04 \%$ of the sum of squares of the interaction of the variation, and the second (IPCA 2) explained $33.12 \%$, totaling $84.16 \%$ in the first two components. Figure 1 shows the AMMI1 biplot analyses for IPCA $\mathrm{x}$ rubber yield data and the AMMI2 biplot analyses for IPCA 1 x IPCA 2. According to Duarte \& Vencovsky (1999), in AMMI analysis, the biplot is interpreted by the magnitude and the sign of the genotype and environment scores for the interaction axles. Thus, scores close to zero characterize genotypes and 
Table 3. Estimates of phenotypic stability and adaptability obtained by the Lin \& Binns method, with the alteration proposed by Cruz \& Carneiro 2006 and mean rubber yield (grams per tree per tapping) of 25 Hevea brasiliensis genotypes assessed, during six years ${ }^{(1)}$.

\begin{tabular}{|c|c|c|c|c|c|c|c|}
\hline Genotype & Rubber yield & General Pi & Rank & Favorable Pi & Rank & Unfavorable Pi & Rank \\
\hline IAC 40 & 66.7372 & 18.8244 & 1 & 6.9162 & 1 & 42.6409 & 1 \\
\hline IAC 301 & 55.2256 & 169.6429 & 2 & 192.6872 & 4 & 123.5543 & 4 \\
\hline IAC 300 & 52.7217 & 189.2094 & 3 & 243.2734 & 6 & 81.0813 & 3 \\
\hline IAC 56 & 54.3983 & 189.3249 & 4 & 169.4281 & 3 & 229.1185 & 6 \\
\hline RRIM 600 & 50.0683 & 219.5556 & 5 & 212.1379 & 5 & 234.3909 & 7 \\
\hline IAC 303 & 52.5911 & 220.6021 & 6 & 158.9637 & 2 & 343.8791 & 10 \\
\hline RO 45 & 51.4944 & 231.4335 & 7 & 252.5771 & 7 & 189.1463 & 5 \\
\hline IAN 3156 & 48.7189 & 392.1168 & 8 & 558.3374 & 12 & 59.6756 & 2 \\
\hline IAC 307 & 42.6317 & 407.0212 & 9 & 396.9746 & 8 & 427.1145 & 12 \\
\hline IAC 302 & 41.4411 & 449.8353 & 10 & 499.1332 & 10 & 351.2396 & 11 \\
\hline IAC 313 & 39.4367 & 501.9152 & 11 & 493.7025 & 9 & 518.3408 & 16 \\
\hline IAC 308 & 39.7683 & 503.7598 & 12 & 520.8373 & 11 & 469.6047 & 13 \\
\hline IAN 3703 & 38.6322 & 562.6114 & 13 & 607.4329 & 13 & 472.9684 & 14 \\
\hline Fx 3899 & 38.3161 & 588.9922 & 14 & 741.7744 & 14 & 283.4279 & 8 \\
\hline Fx 985 & 36.3861 & 630.8047 & 15 & 798.6014 & 17 & 295.2112 & 9 \\
\hline IAC 309 & 34.3839 & 682.6774 & 16 & 764.4721 & 15 & 519.0881 & 17 \\
\hline IAN 4493 & 33.2333 & 731.4238 & 17 & 834.6248 & 18 & 525.0219 & 18 \\
\hline IAN 6721 & 31.9506 & 775.1583 & 18 & 770.7880 & 16 & 783.8991 & 25 \\
\hline IAC 311 & 31.7033 & 787.6565 & 19 & 849.2486 & 20 & 664.4723 & 22 \\
\hline IAN 6323 & 31.4172 & 796.8074 & 20 & 841.1832 & 19 & 708.0559 & 24 \\
\hline IAC 310 & 31.5206 & 799.4209 & 21 & 927.4925 & 22 & 543.2777 & 19 \\
\hline IAC 316 & 30.9200 & 828.5439 & 22 & 919.5880 & 21 & 646.4557 & 21 \\
\hline IAC 312 & 29.0028 & 910.1217 & 23 & $1,062.0425$ & 23 & 606.2803 & 20 \\
\hline IAC 306 & 28.6161 & 956.8838 & 24 & $1,195.7316$ & 25 & 479.1881 & 15 \\
\hline IAC 314 & 26.5094 & $1,022.0931$ & 25 & $1,180.9025$ & 24 & 704.4743 & 23 \\
\hline
\end{tabular}

${ }^{(1)} \mathrm{Pi}$, measure to evaluate phenotypic adaptability and stability.

Table 4. Estimates of harmonic mean of the genetic values (HMGV), relative performance of the genetic values (RPGV), and harmonic mean of the relative performance of the genetic values (HMRPGV) of 25 Hevea brasiliensis genotypes assessed, during six years.

\begin{tabular}{|c|c|c|c|c|c|c|c|c|}
\hline Genotype & Order & HMGV & Genotype & Order & RPGV & Genotype & Order & HMRPGV \\
\hline IAC 40 & 1 & 64.136 & IAC 40 & 1 & 1.7971 & IAC 40 & 1 & 1.7597 \\
\hline IAN 3156 & 2 & 46.394 & IAC 300 & 2 & 1.3352 & IAC 300 & 2 & 1.3271 \\
\hline IAC 300 & 3 & 43.210 & IAN 3156 & 3 & 1.3297 & IAC 301 & 3 & 1.2705 \\
\hline IAC 301 & 4 & 41.433 & IAC 301 & 4 & 1.3014 & IAN 3156 & 4 & 1.2579 \\
\hline IAC 303 & 5 & 38.766 & IAC 56 & 5 & 1.2221 & IAC 56 & 5 & 1.1982 \\
\hline RRIM 600 & 6 & 38.128 & RO 45 & 6 & 1.2167 & RO 45 & 6 & 1.1873 \\
\hline IAC 56 & 7 & 37.423 & IAC 303 & 7 & 1.1990 & IAC 303 & 7 & 1.1714 \\
\hline RO 45 & 8 & 37.279 & RRIM 600 & 8 & 1.1551 & RRIM 600 & 8 & 1.1528 \\
\hline IAC 302 & 9 & 33.038 & IAC 302 & 9 & 1.0487 & IAC 302 & 9 & 1.0331 \\
\hline IAC 310 & 10 & 32.400 & IAC 307 & 10 & 0.9767 & IAC 307 & 10 & 0.9639 \\
\hline IAN 4493 & 11 & 32.235 & IAN 4493 & 11 & 0.9355 & IAC 313 & 11 & 0.9302 \\
\hline Fx 985 & 12 & 31.790 & IAC 313 & 12 & 0.9352 & IAC 310 & 12 & 0.9246 \\
\hline IAC 309 & 13 & 31.155 & IAC 310 & 13 & 0.9306 & IAN 4493 & 13 & 0.9126 \\
\hline IAC 313 & 14 & 30.583 & IAC 308 & 14 & 0.9226 & IAC 308 & 14 & 0.9103 \\
\hline IAC 308 & 15 & 30.284 & IAC 309 & 15 & 0.9103 & IAC 309 & 15 & 0.9051 \\
\hline IAC 307 & 16 & 30.006 & Fx 985 & 16 & 0.8821 & Fx 985 & 16 & 0.8489 \\
\hline IAN 3703 & 17 & 27.197 & IAN 3703 & 17 & 0.8400 & IAN 3703 & 17 & 0.8192 \\
\hline IAC 306 & 18 & 26.265 & Fx 3899 & 18 & 0.7959 & IAN 6323 & 18 & 0.7821 \\
\hline IAN 6323 & 19 & 26.250 & IAN 6323 & 19 & 0.7920 & Fx 3899 & 19 & 0.7700 \\
\hline IAC 312 & 20 & 25.428 & IAC 312 & 20 & 0.7827 & IAC 312 & 20 & 0.7675 \\
\hline IAC 316 & 21 & 24.683 & IAN 6721 & 21 & 0.7739 & IAC 311 & 21 & 0.7311 \\
\hline IAC 314 & 22 & 23.952 & IAC 311 & 22 & 0.7494 & IAN 6721 & 22 & 0.7236 \\
\hline Fx 3899 & 23 & 23.718 & IAC 306 & 23 & 0.7417 & IAC 306 & 23 & 0.7200 \\
\hline IAC 311 & 24 & 23.393 & IAC 314 & 24 & 0.7147 & IAC 314 & 24 & 0.7114 \\
\hline IAN 6721 & 25 & 20.132 & IAC 316 & 25 & 0.7118 & IAC 316 & 25 & 0.6999 \\
\hline
\end{tabular}



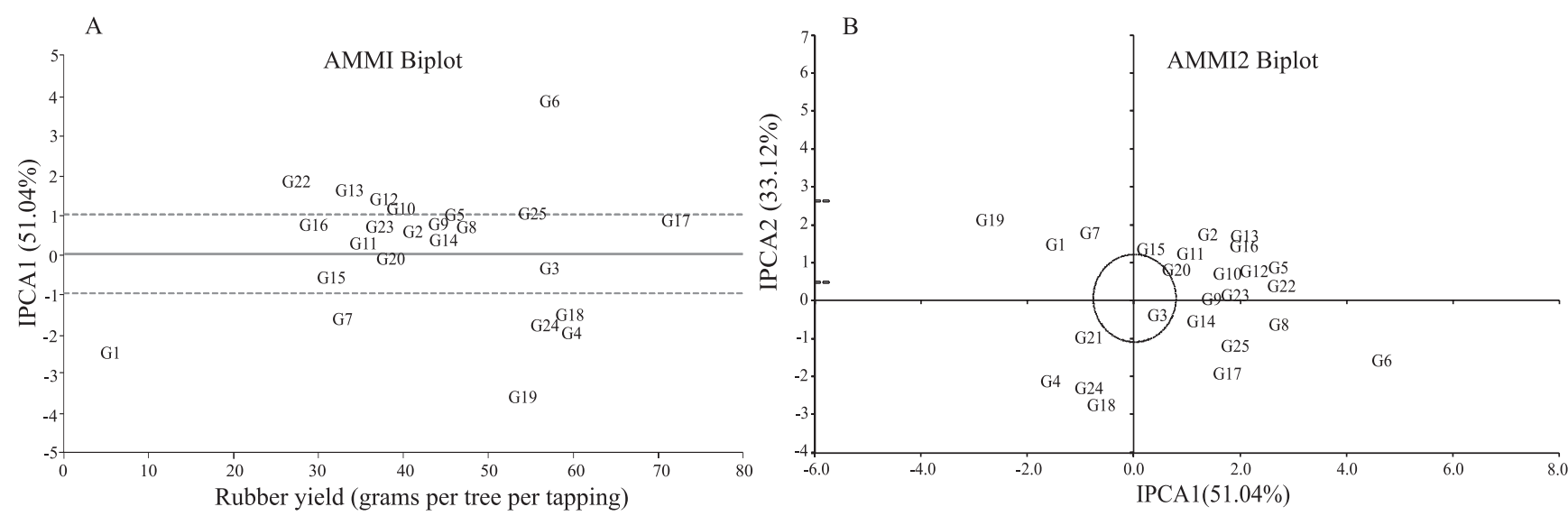

Figure 1. AMMI biplot analyses for data of IPCA $x$ rubber yield and AMMI2 biplot analyses for IPCA1 x IPCA2. The following genotypes were evaluated: G1 (Fx 3899), G2 (Fx 985), G3 (IAC 300), G4 (IAC 301), G5 (IAC 302), G6 (IAC 303), G7 (IAC 306), G8 (IAC 307), G9 (IAC 308), G10 (IAC 309), G11 (IAC 310), G12 (IAC 311), G13 (IAC 312 ), G14 (IAC 313 ), G15 (IAC 314), G16 (IAC 316), G17 (IAC 40), G18 (IAC 56), G19 (IAN 3156), G20 (IAN 4493), G21 (IAN 3703 ), G22 (IAN 6323), G23 (IAN 6721), G24 (RO 45), and G25 (RRIM 600).

environments that contribute little to interaction, i.e., are stable. In the AMMI2 biplot, stable genotypes and environments are those whose points are close to zero for the two interaction axles (IPCA1 x IPCA2). The most stable genotypes in the AMMI biplot were IAC 310, IAN 4493, IAN 6721, IAC 313, IAC 314, and IAC 307, all with low yield. IAC 40 and IAC 300 were among the high yielding and stable genotypes, as observed in previous analyses. The results found for stable genotypes, but with lower yield, were in line with those found with the Wricke method. In AMMI2, genotypes IAN 4493, IAC 300, and IAC 314 were considered stable.

There was coherence among the most stable genotypes identified with the different analytical methods; however, the ranking of some genotypes was altered. IAC 40 and IAC 300 were considered the most stable in the analyses that associated stability to yield. From the breeder's point of view, processing data by several methods of adaptability and stability analysis, while considering the peculiarities of each method, is better for decision-making when indicating cultivars (Cargnelutti Filho et al., 2007). When the genotype $\mathrm{x}$ environment interaction results in the variation of unpredictable environmental factors, such as year to year variation, as was the case in the present study, breeders need to develop more stable genotypes that can perform reasonably well in a wide range of conditions. Such breeding strategies can help rubber producers to avoid risks (Gonçalves et al., 2008).

\section{Conclusions}

1. The simultaneous use of different methods leads to a more accurate indication of stable Hevea brasiliensis genotypes.

2. Stability analyses based on different principles show agreement in indicating stable $H$. brasiliensis genotypes.

\section{Acknowledgements}

To Fundação de Amparo à Pesquisa do Estado de São Paulo, and to Conselho Nacional de Desenvolvimento Científico e Tecnológico, for financial support.

\section{References}

CARGNELLUTI FILHO, A.; PERECIN, D.; MELHEIROS, E.B.; GUADAGNIN, J.P. Comparação de métodos de adaptabilidade e estabilidade relacionados à produtividade de grãos de cultivares de milho. Bragantia, v.66, p.571-578, 2007.

CHANDRASEKHAR, T.R.; MARATTUKALAM, J.G.; MERCYKUTTY, V.C.; PRIYADARSHAN, P.M. Age of yield stabilization and its implications for optimizing selection and shortening breeding cycle in rubber (Hevea brasiliensis Muell. Arg.). Euphytica, v.156, p.67-75, 2007.

CRUZ, C.D. Programa Genes: análise multivariada e simulação. Viçosa: UFV, 2006. 175p. 
CRUZ, C.D.; CARNEIRO, P.C.S. Modelos biométricos aplicados ao melhoramento genético. Viçosa: UFV, 2006. v.2, 585p.

CRUZ, C.D.; REGAZZI, A.J.; CARNEIRO, P.C.S. Modelos biométricos aplicados ao melhoramento genético. Viçosa: UFV, 2004. 480p.

DUARTE, J.B.; VENCOVSKY, R. Interação genótipo x ambiente: uma introdução à análise "AMMI". Ribeirão Preto: Sociedade Brasileira de Genética, 1999. 60p. (SBG. Série monografias, 9).

EBERHART, S.A.; RUSSELL, W.A. Stability parameters for comparing varieties. Crop Science, v.6, p.36-40, 1966.

GAUCH, H.G. Model selection and validation for yield trials with interaction. Biometrics, v.44, p.705-715, 1988.

GAUCH, H.G.; ZOBEL, R.W. Predictive and postdictive success of statistical analyses of yield trials. Theoretical and Applied Genetics, v.76, p.1-10, 1988

GONÇALVES, P. de S.; BORTOLETTO, N.; CARDINAL, Á.B.B.; GOUVÊA, L.R.L.; COSTA, R.B. de; MORAES, M.L.T. Age-age correlation for early selection of rubber tree genotypes in São Paulo State, Brazil. Genetics and Molecular Biology, v.28, p.758-764, 2005.

GONÇALVES, P. de S.; BORTOLETTO, N.; MARTINS, A.L.M.; COSTA, R.B. da; GALLO, P.B. Genotype-environment interaction and phenotypic stability for girth growth and rubber yield of Hevea clones in São Paulo State, Brazil. Genetics and Molecular Biology, v.26, p.441-448, 2003 .

GONÇALVES, P. de S.; MORAES, M.L.T. de; GOUVÊA, L.R.L.; AGUIAR, A.T. da E.; SCALOPPI JUNIOR, J.R. Temporal stability for unpredictable annual climatic variability for Hevea genotype selection. Brazilian Archives of Biology and Technology, v.51, p.11-18, 2008.

GONÇALVES, P. de S.; MORAES, M.L.T. de; SILVA, M. de A.; GOUVÊA, L.R.L.; AGUIAR, A.T. da E.; COSTA, R.B. da. Prediction of Hevea progeny performance in the presence of genotype-environment interaction. Brazilian Archives of Biology and Technology, v.52, p.25-33, 2009.

LIN, C.S.; BINNS, M.R. A superiority measure of cultivar performance for cultivar x location data. Canadian Journal of Plant Science, v.68, p.193-198, 1988.

MAIA, M.C.C.; RESENDE, M.D.V. de; PAIVA, J.R. de; CAVALCANTI, J.J.V.; BARROS, L. de M. Seleção simultânea para produção, adaptabilidade e estabilidade genotípicas em clones de cajueiro, via modelos mistos. Pesquisa Agropecuária Tropical, v.39, p.43-50, 2009.

MELO, L.C.; MELO, P.G.; FARIA, L.C. de; CABRERA DIAZ, J.L.; DEL PELOSO, M.J.; RAVA, C.A.; COSTA, J.G.C. da. Interação com ambientes e estabilidade de genótipos de feijoeiro-comum na Região Centro-Sul do Brasil. Pesquisa Agropecuária Brasileira, v.42, p.715-723, 2007.

NASCIMENTO FILHO, F.J. do; ATROCH, A.L;; CRUZ, C.D.; CARNEIRO, P.C.S. Adaptabilidade e estabilidade de clones de guaraná. Pesquisa Agropecuária Brasileira, v.44, p.1138-1144, 2009.

PEREIRA, H.S.; MELO, L.C.; DEL PELOSO, M.J.; FARIA, L.C. de; COSTA, J.G.C. da; CABRERA DÍAZ, J.L.; RAVA, C.A.;
WENDLAND, A. Comparação de métodos de análise de adaptabilidade e estabilidade fenotípica em feijoeiro-comum. Pesquisa Agropecuária Brasileira, v.44, p.374-383, 2009a.

PEREIRA, H.S.; MELO, L.C.; FARIA, L.C. de; DEL PELOSO, M.J.; COSTA, J.G.C. da; RAVA, C.A.; WENDLAND, A. Adaptabilidade e estabilidade de genótipos de feijoeiro-comum com grãos tipo carioca na Região Central do Brasil. Pesquisa Agropecuária Brasileira, v.44, p.29-37, 2009b.

PRIYADARSHAN, P.M.; DEY, S.K.; NAZEER, M.A.; VARGHESE, Y.A.; KANG, M.S. Adaptability analysis of rubber (Hevea Brasiliensis Muell.-Arg.) clones via GGE Biplot. Journal of Rubber Research, v.11, p.237-244, 2008.

PRIYADARSHAN, P.M.; GONÇALVES, P. de S.; OMOKHAFE, K.O. Breeding Hevea rubber. In: JAIN, S.M.; PRIYADARSHAN, P.M. (Ed.). Breeding plantation tree crops: tropical species. New York: Springer Science, 2009. p.469-524.

RESENDE, M.D.V. de. Métodos estatísticos ótimos na análise de experimentos de campo. Colombo: Embrapa Florestas, 2004. 57p. (Embrapa Florestas. Documentos, 100).

RESENDE, M.D.V. de. SELEGEN REML/BLUP: sistema estatístico e seleção genética computadorizada via modelos lineares mistos. Colombo: Embrapa Florestas, 2007. 359p.

RESENDE, M.D.V. de; DUARTE, J.B. Precisão e controle de qualidade em experimentos de avaliação de cultivares. Pesquisa Agropecuária Tropical, v.37, p.182-194, 2007.

RESENDE, M.D.V. de; STURION, J.A.; HIGA, A.R. Comparação entre métodos de avaliação da estabilidade fenotípica e adaptabilidade aplicados a dados de Eucalyptus cloeziana (F. Muell). Boletim de Pesquisa Florestal, n.42, p.3-34, 2001.

ROSSE, L.N.; VENCOVSKY, R.; FERREIRA, D.F. Comparação de métodos de regressão para avaliar a estabilidade fenotípica em cana-de-açúcar. Pesquisa Agropecuária Brasileira, v.37, p.25-32, 2002.

SAS INSTITUTE. SAS: user's guide. Versão 9.1.3. Cary: SAS Institute, 2002.

SILVAFILHO, J.L. da; MORELLO, C. deL.; FARIAS, F.J.C.; LAMAS, F.M.; PEDROSA, M.B.; RIBEIRO, F.L. Comparação de métodos para avaliar a adaptabilidade e estabilidade produtiva em algodoeiro. Pesquisa Agropecuária Brasileira, v.43, p.349-355, 2008.

SILVA, W.C.J. e; DUARTE, J.B. Métodos estatísticos para estudo de adaptabilidade e estabilidade fenotípica em soja. Pesquisa Agropecuária Brasileira, v.41, p.23-30, 2006.

VERARDI, C.K.; RESENDE, M.D.V. de; COSTA, R.B. da; GONÇALVES, P. de S. Adaptabilidade e estabilidade da produção de borracha e seleção em progênies de seringueira. Pesquisa Agropecuária Brasileira, v.44, p.1277-1282, 2009.

WRICKE, G. Zur Berechning der Okovalenz bei Sommerweizen und Hafer. Zeitschrift fur Pflanzenzuchtung, v.52, p.127-138, 1965.

ZOBEL, R.W.; WRIGHT, M.J.; GAUCH, H.G. Statistical analysis of a yield trial. Agronomy Journal, v.80, p.388-393, 1988.

Received on January 28, 2011 and accepted on May 20, 2011 